\title{
INFLUENCE OF PULSED SHORT WAVE (DIAPULSE) TREATMENT ON THE BIOCHEMICAL PARAMETERS CORTISOL AND ALDOSTERONE
}

\author{
Dogaru Gabriela ${ }^{1,2}$
}

\author{
${ }^{1}$ Clinical Rehabilitation Hospital Cluj-Napoca \\ 2“Iuliu Haţieganu” University of Medicine and Pharmacy Cluj-Napoca
}

\begin{abstract}
Pulsed short waves are part of high frequency therapy; unlike continuous short waves, where the phenomenon of tissular endothermia occurs, they have therapeutic effects that seem to depend rather on the interaction of electromagnetic waves with biological tissue, as they act only through specific electromagnetic energy. The recommended work technique for the use of the Diapulse device is that regardless of the exposed somatic region, there will be an initial exposure of one of the following regions: prehepatic, epigastric or lumbar (for action on the adrenal glands). Considering the role and the effects of the hormones of the adrenocortical gland, particularly glucocorticoids, on the body, which influence the inflammatory response of the connective tissue, with a role in rheumatoid pathology, we monitored the changes in the function of this gland. The biochemical parameters cortisol and aldosterone were quantitatively assessed in patients with complex regional pain syndrome type I (algoneurodystrophy) treated with pulsed short waves, who were initially exposed to radiation of the lumbar region. In the same treatment session, all patients were exposed to radiation of the lumbar region, at a dose of 4/400 impulses/sec., for 10 minutes, followed by radiation of the affected region at a dose of 6/600 impulses/sec., for 10 minutes. There was one treatment session per day, for 14 days. It was demonstrated that radiation of the lumbar region at a dose of 4/400 impulses/sec. caused no changes in the hormonal function of the adrenal gland, i.e. no hypo- or hyperfunction; there was no overstrain or overstress after exposure to pulsed short waves, which is an important aspect, with applicability in clinical practice. Studies demonstrated both the local and the general, systemic influence of pulsed short waves, the induced changes being for the most part strictly dependent on the dose used.
\end{abstract}

Keywords: pulsed short waves, Diapulse, cortisol, aldosterone, adrenal glands 


\section{Introduction}

Pulsed short waves are part of high frequency therapy; unlike short continuous waves, where the phenomenon of tissular endothermia occurs, they have therapeutic effects that seem to depend rather on the interaction of electromagnetic waves with biological tissue, as they act only through specific electromagnetic energy. The biological effects of these pulsed short waves could be explained by an activation of cellular enzymatic reactions, a stimulation of cellular energy metabolism and a stimulation of hepatic and adrenal function and of the connective vascular system [1].

The recommended work technique for the use of the Diapulse device is that regardless of the exposed somatic region, there will be an initial exposure of one of the following regions: prehepatic, epigastric or lumbar (for action on the adrenal glands) [2].

The adrenal gland is enclosed in a connective capsule, and the gland stroma consists of three zones: glomerular, fascicular and reticular, while in the center, the medullary area is found. The glomerular zone is right below the capsule, being relatively thin. It is formed by cells arranged in arcuate clusters. Characteristically, in rats, the cells appear approximately spherical, with a central nucleus and the cytoplasm loaded with lipid droplets. The cells of this zone synthesize and secrete mineralocorticoid hormones that ensure fluid and electrolyte balance and control, i.e. aldosterone and deoxycorticosterone [3, 4].

The fascicular zone is the most developed, covering over $70 \%$ of the adrenal cortex. Its cells synthesize and secrete glucocorticoid hormones: cortisol, corticosterone, playing a major role in carbohydrate, protein and lipid metabolism. In addition to their role in the regulation of lipid, protein and carbohydrate metabolism, glucocorticoid hormones secreted by the fascicular zone cells have effects on the inflammatory response of connective tissue and on the immune system. This is why glucocorticoids are widely used in the treatment of allergies, arthritis, various rheumatoid diseases and other inflammatory disorders.

The reticular zone cells synthesize and produce sexual steroid hormones: estrogen, androgen and progesterone $[3,4]$.

Considering the role and effects of the hormones of the adrenocortical gland, particularly glucocorticoids, on the body, which influence the inflammatory response of the connective tissue, with a role in rheumatoid pathology, we monitored the changes in the function of this gland. The biochemical parameters cortisol and aldosterone were quantitatively assessed in patients with complex regional pain syndrome type I (algoneurodystrophy) treated with pulsed short waves, who were initially exposed to radiation of the lumbar region.

Optical and electron microscopic studies carried out as part of experimental research evidenced cellular and subcellular changes in the adrenal glands taken from Wistar rats exposed to pulsed short waves of various intensities, compared to the same organ of untreated control animals. In the unexposed control group, no cellular or subcellular changes were found $[5,6]$.

In the experimental control group irradiated at a dose of 1/80 impulses/sec., optical and electron microscopic studies showed a slight increase in metabolic processes compared to the control group, and a slight stimulation of hormone synthesis and secretion, particularly in the fascicular and reticular zones. Mitochondria were normally structured and through their high numbers, they showed an optimal activity of energy metabolism. There were no side effects $[5,6]$.

In the experimental group irradiated at a dose of 4/400 impulses/sec., structural and ultrastructural studies evidenced in all three zones of the adrenocortical gland an increase of hormone synthesis and secretion processes compared to the control group and the group irradiated at a dose of 1/80 impulses/sec., an 
intensification of energy metabolism in providing the energy required for increased hormone production, an enhancement of collagen fiber synthesis in the capsule, necessary for healing. It was demonstrated that at this dose, an increase of hormone synthesis and secretion and a stimulation of adrenal function occurred [5].

The general picture of images obtained from all adrenocortical zones in the experimental group irradiated at a dose of $6 / 600$ impulses/sec. shows a slight diminution of hormone synthesis and secretion activity, but within the limits found in the control group. Small lysis and cellular necrosis foci are seen. Some cell mitochondria have a slightly rarefied mitochondrial matrix, which indicates a decrease of energy metabolic capacity. For experimental animals, this dose is probably too strong, inducing a state of stress [5].

Histoenzymological studies demonstrate a moderate increase in the activity of mitochondrial enzymes: magnesium-dependent adenosine triphosphatase (ATPase), cytochrome oxidase (CyOx), succinate dehydrogenase (SDH), monoamine oxidase (MAO), particularly in the group irradiated at $4 / 400$ impulses/sec.

Given that SDH participates in the Krebs cycle, CyOx participates in terminal oxidation, and ATPase participates in membrane transport and energy metabolism, in the experimental group irradiated at 4/400 impulses/sec. there was a moderate increase in the activity of enzymes participating in energy metabolism [7].

\section{Materials and methods}

Patients. The study included 40 patients aged between 23-74 years with complex regional pain syndrome type I, posttraumatic stages 1 and 2: 4 dislocations, 36 hand and ankle fractures. The study was carried out at the Clinical Rehabilitation Hospital Cluj-Napoca, in the period
September 2009 - November 2011. The duration of immobilization for all patients was 3-6 weeks. Before their inclusion in the study, the informed consent of the patients was obtained. Patients with pacemakers were excluded from the study.

Study design. The study, a prospective longitudinal analysis, was carried out on a representative sample. Pulsed short wave treatment was performed with the Diapulse device. In the same treatment session, the lumbar region of all patients was irradiated (for action on the adrenal gland), using the dose of 4/400 impulses/sec., for 10 minutes, followed by exposure of the affected region at a dose of 6/600 impulses/sec., for 10 minutes. There was one treatment session per day, for 14 days. Over the duration of treatment, patients received no other drug or physicalkinetic therapy. The biochemical parameters cortisol and aldosterone were determined. The samples were collected in the morning, before and after treatment, in order to evaluate the adrenal gland function considering the application of treatment to both the lumbar region and the affected region.

Statistical metods. Data were collected and analyzed using the Excel Microsoft 2007 application [8]. The $\mathrm{T}$ test for the comparison of the means in paired samples and the $F$ test for the comparison of variations were applied [9]. The significance threshold for the tests used was $\mathrm{p}=0.05$.

\section{Results}

Regarding cortisol, on day 1 , before the pulsed short wave treatment, values ranged between $76 \mathrm{ng} / \mathrm{ml}$ and $195 \mathrm{ng} / \mathrm{ml}$. The mean of this variable was 124.9, with a standard deviation of 25.18 , the $95 \%$ confidence interval being [116.84, 132.96] (Table 1, Fig. $1)$. 
The interval was divided into frequency classes, and the frequency class table and the histogram are presented below.

\begin{tabular}{ccc} 
Class & Frequency & Percent \\
\hline $\begin{array}{c}\text { less than } 100 \\
\mathrm{ng} / \mathrm{ml}\end{array}$ & 8 & $20 \%$ \\
\hline $\begin{array}{c}(100,125] \\
\mathrm{ng} / \mathrm{ml}\end{array}$ & 16 & $40 \%$ \\
\hline $\begin{array}{c}(125,150] \\
\mathrm{ng} / \mathrm{ml}\end{array}$ & 7 & $17.5 \%$ \\
\hline $\begin{array}{c}(150,175] \\
\mathrm{ng} / \mathrm{ml}\end{array}$ & 8 & $20 \%$ \\
\hline $\begin{array}{c}\text { more than } 175 \\
\mathrm{ng} / \mathrm{ml}\end{array}$ & 1 & $2.5 \%$ \\
\hline
\end{tabular}

Table 1. Cortisol values (ng/ml) before treatment

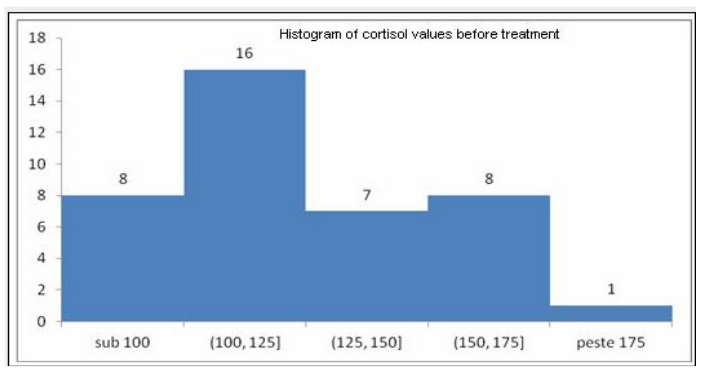

Fig. 1. Histogram of cortisol values (ng/ml) before treatment

After exposure, cortisol values increased in 9 patients $(22.5 \%)$, remained constant in 1 patient $(2.5 \%)$ and decreased in 30 patients (75\%) (Fig. 2).

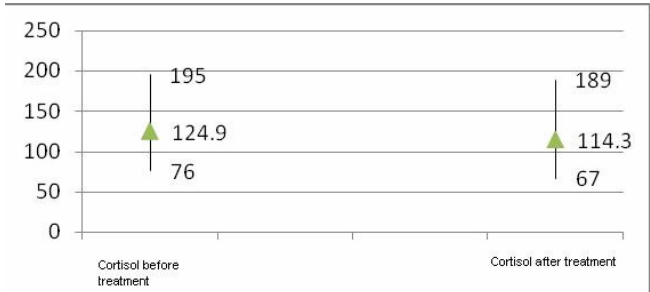

Fig. 2. Comparison of the patients' cortisol values $(\mathrm{ng} / \mathrm{ml})$ before and after treatment

By comparing the means before and after treatment (124.9 vs 114.3) using the paired t test, the $\mathrm{p}$ value obtained was lower than $0.05(\mathrm{p}=0.01)$, so, the cortisol mean after exposure was significantly lower than the cortisol mean before exposure.

Regarding aldosterone, on day 1 , values ranged between $34 \mathrm{pg} / \mathrm{ml}$ and $470 \mathrm{pg} / \mathrm{ml}$. The mean of this variable was 139.325 , with a standard deviation of 97.22 , the $95 \%$ confidence interval being [108.23, 170.42] (Table 2, Fig. 3).

The interval was divided into frequency classes, and the frequency class table and the histogram are presented below.

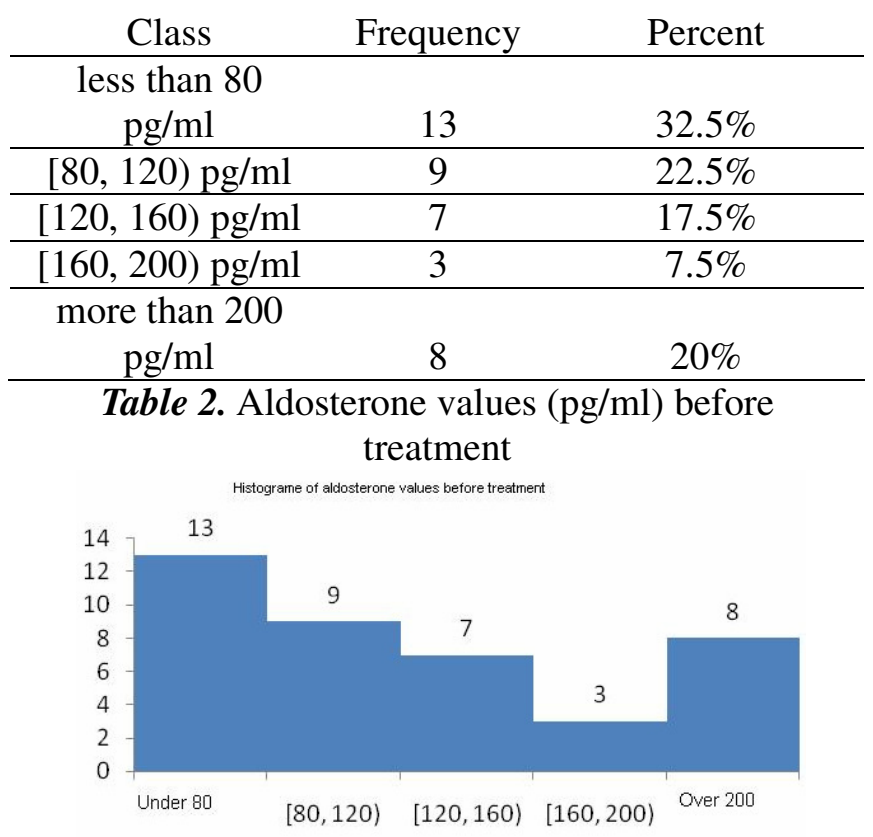

Fig. 3. Histogram of aldosterone values before treatment

After exposure, aldosterone values increased in 6 patients $(15 \%)$ and decreased in 34 patients (85\%) (Fig. 4).

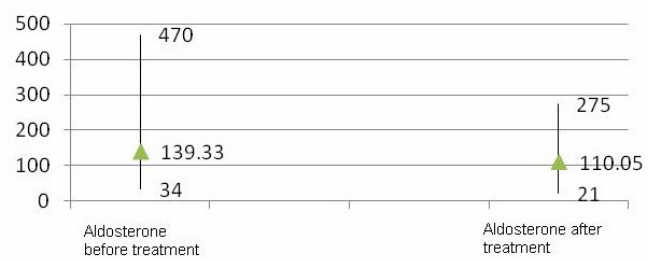

Fig. 4. Comparison of the patients' aldosterone values $(\mathrm{pg} / \mathrm{ml})$ before and after treatment 
By comparing the means before and after treatment (139.325 vs 110.05) using the paired t test, the $\mathrm{p}$ value obtained was lower than $0.05(\mathrm{p}=0.008)$, so the aldosterone mean after exposure was significantly lower than the aldosterone mean before exposure.

The mean cortisol and aldosterone values after treatment were significantly lower compared to the mean values obtained before treatment, but they ranged within normal value limits.

\section{Discussion}

The maintenance of the homeostasis of the animal and human body requires a continuous behavioral, vegetative and endocrine adaptation to counteract the negative effects of external and internal factors that continuously tend to change the equilibrium of the organism. The major response of the body to the action of stress factors is the activation of the hypothalamopituitary-adrenocortical axis, which consists of the rapid release of corticoliberin and adrenocorticotropic hormone (ACTH), immediately followed by an increase in plasma glucocorticoid concentrations [10].

Glucocorticoid hormones, including the main active hormone cortisol, are hormones essential for life.

Through their actions, they allow the body to regulate the anabolism-catabolism ratio for an effective function of cellular metabolism.

Cortisol is the most important natural protective factor of cell membranes (particularly the plasma membrane and the lysosomal membrane). At nuclear level, cortisol stimulates the formation of messenger ribonucleic acid (mRNA) for the synthesis of macrocortin, a PLA2 inhibitor, which is required for the stimulation of arachidonate derivatives in lipid membranes.

Glucocorticoids have multiple actions: on carbohydrate, protein, lipid, water- mineral metabolism; on the cardiovascular, digestive, nervous, hematopoietic system.

In the skeletal system, they induce osteoporosis, osteomalacia, aseptic necrosis, they inhibit the synthesis of mucopolysaccharides in cartilage.

They also play an antiinflammatory role, they decrease the number of lymphocytes and fibroblasts, they stabilize lysosomal membranes [11].

Most of the circulating cortisol undergoes glucuronoconjugation in the liver. A certain amount of cortisol is converted to cortisone in the liver and is rapidly glucuronoconjugated.

Overstrain induced by surgery and other forms of stress delays the hepatic degradation of glucocorticoids and the circulating free cortisol concentration increases [10].

The main mineralocorticoid hormone is aldosterone, whose principal action is to maintain water and sodium ions constant in the body [11].

Some researchers have demonstrated that during the first stages of the body exposure to stress conditions, the adrenal gland rapidly reacts through the hypertrophy of the cortex, particularly in the fascicular zone, and glucocorticoid hormones, which initially play an antiinflammatory and gluconeogenetic and lipolytic role, reach very high levels. The stimulation of the adrenocortical gland is followed at molecular level by a coordinated rarefaction of the actin network, particulary through the depolymerization of microfilaments. This is the mechanism that enables the release of important amounts of hormones in a short time period [12].

Under the conditions of prolonged stress exposure, the physiological exhaustion of the gland occurs, which manifests by a reduction of cortical thickness, particularly in the fascicular zone [13], a diminution of adrenocortical synthesis [14], as well as by an increase in the lacunarity of the medulla. 


\section{Conclusions}

The mean cortisol and aldosterone values after pulsed short wave treatment were significantly lower compared to the mean values obtained before treatment.

It was demonstrated that the radiation of the lumbar region at a dose of 4/400 impulses/sec. induced no changes in the hormonal function of the adrenal gland, i.e. no hypo- or hyperfunction; there was no overstrain or overstress after exposure to pulsed short waves, which is an important aspect, with applicability in clinical practice.

The studies demonstrated both the local and the general, systemic influence of pulsed short waves, the induced changes being for the most part strictly dependent on the dose used.

\section{References}

1. Pop L. Cercetări clinico-experimentale asupra efectelor biologice şi terapeutice ale undelor scurte pulsatile (Diapulse). Teză de doctorat. U.M.F. „Iuliu Haţieganu”. ClujNapoca, 1985.

2. Rădulescu A. Electroterapie. Editura Medicală Bucureşti, 2004 .

3. Saragea M.Tratat de fiziopatologie. Vol 1. Editura Academiei Romane 1985.

4. Floarea A, Crăciun C, Puică C. Modificări structurale şi ultrastructurale produse în glandele suprarenale după administrarea experimentală a veninului de albine. Studia Universitatis Babeş-Bolyai, Biologia 2005; 2: 111-125.

5. Dogaru BG, Crăciun C, Toader S, Tripon S, Pop L. Structural and ultrastructural changes in the adrenal glands of rats undergoing pulsed short wave treatment. Annals of RSCB 2009; dec XIV (2): 80-86).

6. Dogaru BG, Crăciun C, Cătoi C, Toader S, Pop L. Histological changes in organs and tissues of rats undergoing pulsed short wave treatment. Annals of RSCB 2009; dec XIV (2) : 73-79).

7. Dogaru BG, Crăciun C, Rusu M, Bódizs G, Călinici T, Pop L. Histoenzymological and biochemical cortisol and aldosterone changes in rats exposed to pulsed short waves (Diapulse). Annals of RSCB 2010; dec. XV (2): 79-86 .

8. http://office.microsoft.com/en-us/excelhelp/office-excel-2007-product-overviewHA010165632.aspx oct. 2010

9. Drugan T, Colosi H, Bolboaca S, Achimas A, Tigan . Inferența datelor statistice, Editura Alma Mater 2003.

10. Kis E, Crăciun C. Efecte secundare ale unor glucocorticoizi topici. Editura Risoprint Cluj- Napoca, 2005.

11. Saragea M.Tratat de fiziopatologie.Vol 1. Editura Academiei Romane 1985.

12. Floarea A, Crăciun C, Puică C. Modificări structurale şi ultrastructurale produse în glandele suprarenale după administrarea experimentală a veninului de albine. Studia Universitatis Babeş-Bolyai, Biologia 2005; 2: 111-125.

13. Feldman D, Funder J W, Edelman J S. Subcellular mechanism in the action of adrenal steroids. Am J Med .1972; 53: 545560 .

14.McBeth J, Chiu Y H, Silman A, Ray D, Morriss D, Dicksens C, et al. Hypothalamic pituitary adrenal stress axix function and the relationship with chronic widespread pain and its antecedents. Arthritis Res. Ther. 2005; 7-5. 